Génét. Sél. Evol., 1988, 20 (3), 357-366

\title{
Reaction to halothane anaesthesia among heterozygotes at the halothane locus in British Landrace pigs
}

\author{
O.I. SOUTHWOOD, S.P. SIMPSON and A.J. WEBB * \\ Agricultural and Food Research Council, Institute of Animal Physiology and Genetics Research **, \\ Edinburgh Research Station, West Mains Road, Edinburgh, EH9 $3 J Q$, United Kingdom
}

\begin{abstract}
Summary
The probability of heterozygotes at the halothane locus reacting to halothane anaesthesia was investigated using five generations of British Landrace pigs selected for positive or negative reaction to halothane. Various models of inheritance of the halothane reaction were tested using maximum likelihood. In general, within the selection lines, a recessive model in which no heterozygotes react adequately described the data. The positive and negative selection lines were crossed at generations 3,4 and 5 and an average proportion of 0.20 of offspring from matings between the lines reacted to halothane. However, after allowing for the presence of heterozygous parents in the negative line, the probability of a heterozygous offspring reacting was estimated to be less than 0.03 . The incidence of halothane reaction was higher in offspring born out of positive than out of negative dams $(0.28 v 0.12, P<0.01)$ when crossed to negative and positive sires respectively. This difference could not be completely explained by heterozygosity in the negative selection line, suggesting some form of maternal effect on the probability of a heterozygote reacting. The genetic nature of this effect was examined by backcrossing putative heterozygous females to halothane positive and negative males. The backcross suggested that the maternal effect was due to maternal environment rather than cytoplasmic inheritance.
\end{abstract} pigs.

Key words : halothane reaction, inheritance, heterozygotes, maternal effects, British Landrace

\section{Résumé}

Sensibilité à l'halothane chez des porcs de race Landrace britannique hétérozygotes au locus halothane

La probabilité qu'un animal hétérozygote au locus de sensibilité à l'halothane réagisse à cet anesthésique a été déterminée à partir de cinq générations de porcs Landrace britannique sélectionnés pour leur sensibilité ou leur résistance à l'halothane. Différents modèles d'héritabilitié du caractère ont été analysés. Généralement, au sein des lignées sélectionnées, un modèle récessif, dans lequel aucun animal hétérozygote n'est sensible, apparaît cohérent avec nos données. Les lignées sensible et résistante obtenues par sélection ont été croisées aux $3^{\mathrm{e}}, 4^{\mathrm{e}}$ et $5^{\mathrm{e}}$ générations et une proportion globale de $20 \%$ des descendants s'est avérée sensible à l'halothane. Cependant, en tenant compte de la présence de parents hétérozygotes dans la lignée résistante, la probabilité

$\left({ }^{*}\right)$ Present adress : Cotswold Pig Development Co. Ltd., Rothwell, Lincoln, LN7 6BJ, United Kingdom.

$\left({ }^{* *}\right)$ Formerly Animal Breeding Research Organisation. 
qu'un descendant hétérozygote soit effectivement sensible a été estimée à moins de $3 \%$. La proportion des descendants réagissant à l'halothane apparaît plus importante chez ceux nés d'une truie elle-même sensible qu'inversement $(28 \%$ contre $12 \% ; P<1 \%)$ lorsqu'elle est croisée à un verrat respectivement négatif ou positif. Cette différence ne peut être uniquement imputée à la présence d'hétérozygotes dans la lignée résistante et suggère un effet maternel sur la probabilité de sensibilité à l'halothane d'un animal hétérozygote. La nature génétique de cet effet a été analysée par croisement en retour de truies supposées hétérozygotes avec des verrats sensibles ou résistants. Nos résultats suggèrent que cet effet serait plutôt lié à un environnement maternel qu'à une hérédité cytoplasmique.

Mots clés : porc, sensibilité à l'halothane, héritabilité, effets maternels, Landrace britannique.

\section{Introduction}

The halothane test is the most widely used method for reducing the incidence of stress susceptibility in commercial practice. This is mainly a result of the ease of application of the test and the apparently simple mode of inheritance of the reaction. Halothane reaction is associated with increased lean proportion but also with transport losses, reduced litter size and poor meat quality (e.g. WEBB et al., 1985).

A pig's reaction to halothane has generally been assumed to be under the control of a single recessive gene $(n)$ with incomplete penetrance of the halothane homozygote $(n n)$. Under this model, animals which are either homozygous normal $(N N)$ or heterozygous $(\mathrm{Nn})$ are halothane negative $(\mathrm{HN})$, whilst the majority of halothane homozygotes are halothane positive (HP) (SMITH \& BAMPTON, 1977 ; Ollivier et al., 1978 ; Eikelenboom et al., 1978 ; MABRY et al., 1981 ; Hanset et al., 1983). The proportion which reacts varies between breed and test procedure (e.g. EIFFERT et al., $1985 a, b$ ) and may be affected by such factors as the sex, age and weight of the animal at test and previous selection for positive reaction. An alternative model in which a proportion of the heterozygotes reacts was proposed by CARDEN et al. (1983) to explain the inheritance of the halothane reaction. Data from the first generation of an experimental line of British Landrace selected for positive or negative reaction to halothane were used to estimate that 0.22 of $\mathrm{Nn}$ individuals reacted to the halothane test.

Data are now available on further generations of these selection lines. These, together with crosses and backcrosses among the lines were used to estimate the penetrance of the halothane reaction in each of the three genotypes. As a result of the increase in homozygosity within the selection lines, the crosses provided a more sensitive test for the presence of heterozygous reactors.

\section{Materials and methods}

\section{A. Animals}

Three groups of data were analysed in this study. Each involved British Landrace pigs selected for positive or negative halothane reaction at the Institute of Animal Physiology and Genetics Research, Edinburgh and maintained either at Mountmarle 
farm, Midlothian or Skedsbush farm, East Lothian. A standard halothane test was used on pigs of 7 to 8 weeks of age (WEBB \& JoRDAN, 1978). As virtually all reactions were seen within the first three minutes of test, the test duration was reduced from $5 \mathrm{~min}$ in generation 1 to $4 \mathrm{~min}$ in generation 2 and 3 minutes in the remaining generations.

\section{Halothane selection lines}

Two selection lines were maintained : the stress susceptible (SS) line selected for halothane reaction and the stress resistant (SR) line selected against halothane reaction. Animals were selected from first parities only, using both the individual's own and its full sibs' halothane phenotypes. In the SR line animals were selected from all $\mathrm{HN}$ litters, and from all HP litters in the SS line. The origin and maintenance of these lines has been reported elsewhere (CARDEN et al., 1983). There was a minimum of 8 sires and 24 litters per generation in each line. Results from the analysis of the first five generations are reported here.

\section{Inter-line crosses}

Animals were mated both within lines (SS $\times$ SS and SR $\times$ SR) and between lines $\left(\mathrm{SS}_{\sigma^{*}} \times \mathrm{SR}_{\varphi}\right.$ and $\left.\mathrm{SR}_{\sigma^{*}} \times \mathrm{SS}_{Q}\right)$ at generation 3 (third parity dams) and generations 4 and 5 (second parity dams) of the selection lines. Each SS and SR sire was mated to both SS and SR females, allowing a within-sire analysis of progeny segregation ratios.

\section{Backcrosses}

Four sets of backcrosses were completed. Female offspring from the between line crosses were backcrossed to boars from both selection lines in backcrosses BC1 and $\mathrm{BC} 2$ and to boars from the SS line only in $\mathrm{BC} 3$ and $\mathrm{BC} 4$. The four possible mating type combinations were : $\mathrm{SR}_{\sigma^{\prime}} \times\left(\mathrm{SS}_{\sigma^{*}} \times \mathrm{SR}_{\mathrm{Q}}\right), \mathrm{SR}_{\sigma^{*}} \times\left(\mathrm{SR}_{\sigma^{*}} \times \mathrm{SS}_{Q}\right), \mathrm{SS}_{\sigma^{\circ}} \times\left(\mathrm{SS}_{\sigma^{\prime}} \times \mathrm{SR}_{Q}\right)$ and $\mathrm{SS}_{\mathrm{O}^{\circ}} \times\left(\mathrm{SR}_{\sigma^{\circ}} \times \mathrm{SS}_{q}\right)$. In $\mathrm{BC} 1, \mathrm{BC} 2$ and $\mathrm{BC} 3$ only $\mathrm{HN}$ dams were used, while both $\mathrm{HN}$ and HP dams were involved in BC4.

\section{B. Genetic analysis}

Maximum likelihood genotype frequencies in parents and penetrances were estimated using both offspring and parental halothane phenotypes. The derivation of the likelihood is based on the methods of Elston \& StewarT (1971) and CanNings et al. (1978). A single locus model for the inheritance of the halothane reaction was assumed and various models of dominance were tested, including a general model in which all penetrances can take values between zero and one, of which the recessive (penetrance of $N N=N n=0, n n \leqslant 1$ ) and partial dominance (penetrance of $N N=0, N n \geqslant 0$ and $n n \leqslant 1)$ are special cases. It was assumed that parents were randomly mated within and between lines and that penetrances for males and females were the same. Parental genotype frequencies were not constrained to be in Hardy-Weinberg equilibrium, due to the continual selection of parents, but were estimated independently.

The likelihood (L) was defined as the probability of observing the data given the genetic model and was calculated conditional on parental phenotypes. Two phenotypes were used : negative or positive reaction to halothane. A small number of doubtful reactors were found and were classed as negative. 
The conditional likelihood for $s$ sires mated to a variable number of dams, $d$, and with a variable number of offspring per dam, $c$, can be written :

$$
\mathrm{L}=\frac{\left[\prod_{s} \sum_{i=1}^{3}\left[\mathrm{~S}_{s}(i) \prod_{d} \sum_{j=1}^{3}\left[\mathrm{D}_{d}(j) \prod_{c} \sum_{k=1}^{3} \mathrm{O}_{c s d}(i, j, k)\right]\right]\right]}{\left[\prod_{s} \sum_{i=1}^{3} \mathrm{~S}_{s}(i)\right]\left[\prod_{d} \sum_{j=1}^{3} \mathrm{D}_{d}(j)\right]}
$$

where $\mathrm{S}_{s}(i)$ is the joint probability of the observed phenotype of sire $s$ and having genotype $i, \mathrm{D}_{d}(j)$ is the joint probability of the observed phenotype of dam $d$, within sire $s$, and having genotype $j$ and $\mathrm{O}_{c s d}(i, j, k)$ is the joint probability of offspring $c$, within dam $d$ and sire $s$, and of having genotype $k$ given parental genotype $s$ are $i$ and $j$. $\mathrm{S}_{s}(i)$ and $\mathrm{D}_{d}(j)$ are functions of the penetrances and the genotype frequencies and $\mathrm{O}_{c s d}(i, j, k)$ is a function of the penetrances and Mendelian transmission frequencies.

Maximum likelihood (ML) estimates of genotype frequency and penetrance and their standard errors were estimated using the package GEMINI (LALOuEL, 1979). A likelihood ratio test was used to compare the fit of models to the data. In this test, $\log \mathrm{L}_{\mathrm{Ho}}$ and $\log \mathrm{L}_{\mathrm{Ha}}$ are the maximum $\log$-likelihoods under the null $(\mathrm{Ho})$ or alternative (Ha) hypothesis. Therefore, under the null hypothesis, $-2\left(\log \mathrm{L}_{\mathrm{Ho}}-\log \mathrm{L}_{\mathrm{Ha}}\right)$ approximately follows a chi-square distribution with $k$ - $p$ degrees of freedom for nested hypotheses, where $k$ and $p$ are the number of parameters estimated under $\mathrm{Ha}$ and $\mathrm{Ho}$ respectively.

The results presented are for the recessive and partial dominance models since other single locus models did not give a significantly better fit to the data. Results from the partial dominance model are only shown if they fitted significantly better than the recessive.

Reciprocal differences between proportions of reactors in $(\mathrm{SR} \times \mathrm{SS})$ and $(\mathrm{SS} \times \mathrm{SR})$ were tested using a chi-square statistic. In backcrosses 1, 2 and 3 the observed incidence of reaction was compared with the expected incidence assuming homozygosity of both lines and a penetrance of $n n=0.90$ using a $t$-test. In backcross 4 the observed incidences were compared with the expected incidences assuming $\mathrm{HN}$ dams were $\mathrm{Nn}$ and HP dams $n n$.

\section{Results}

\section{A. Selection lines}

The incidence of halothane reaction after five generations of selection changed from an initial value of 0.12 in the foundation population to 0.06 in the SR line and 0.91 in the SS line. Maximum likelihood (ML) estimates of genotype frequencies, shown in table 1 , indicate that the SR line still contained a proportion $(0.21$ to 0.55$)$ of $\mathrm{Nn}$ parents up to generation 5 . The SS line was estimated to be homozygous $(n n)$ from generation 3. Although a partial dominance model gave a better fit to the data in 2 out of the 10 cases, the probability of $N n$ reacting $(0.22$ and 0.10$)$ was not significantly different from zero. Therefore, a recessive model provided the most consistent explanation for the inheritance of the halothane reaction over all the data. 
TABLE 1

Maximum likelihood estimates of genotype frequency and penetrance in the British Landrace halothane selection lines

\begin{tabular}{c|c|c|c|c|c|c|c}
\hline \hline \multirow{2}{*}{ Generation } & \multicolumn{9}{|c|}{ SR line } & \multicolumn{2}{c}{\begin{tabular}{c} 
Parental \\
genotype \\
\cline { 2 - 8 }
\end{tabular}} & $\begin{array}{c}\text { No. of } \\
\text { sires }\end{array}$ & \multicolumn{2}{|c|}{$\begin{array}{c}\text { Offspring } \\
\text { tested }\end{array}$} & \multicolumn{2}{c}{\begin{tabular}{c} 
Penetrance \\
\cline { 3 - 8 }
\end{tabular}} & & Total & $\begin{array}{c}\text { Proportion } \\
\text { HP }\end{array}$ & $N N$ & $N n$ & $N n$ & $n n$ \\
\hline & 14 & 214 & 0.06 & 0.45 & 0.55 & 0.00 & 1.00 \\
2 & 8 & 191 & 0.01 & 0.78 & 0.22 & 0.00 & 1.00 \\
3 & 10 & 189 & 0.02 & 0.62 & 0.38 & 0.00 & 1.00 \\
4 & 9 & 189 & 0.02 & 0.79 & 0.21 & $0.10^{(2)}$ & 1.00 \\
5 & 11 & 218 & 0.06 & 0.55 & 0.45 & 0.00 & 1.00 \\
\hline
\end{tabular}

\begin{tabular}{c|c|c|c|c|c|c|c}
\hline \hline \multirow{2}{*}{ Generation } & \multicolumn{9}{|c|}{\begin{tabular}{c} 
SS line \\
\cline { 2 - 8 }
\end{tabular}} & $\begin{array}{c}\text { No. of } \\
\text { sires }\end{array}$ & \multicolumn{2}{|c|}{$\begin{array}{c}\text { Offspring } \\
\text { tested }\end{array}$} & \multicolumn{2}{c}{$\begin{array}{c}\text { Parental } \\
\text { genotype } \\
\text { frequency }\end{array}$} & \multicolumn{2}{c}{ Penetrance } \\
\cline { 3 - 8 } & & Total & $\begin{array}{c}\text { Proportion } \\
\text { HP }\end{array}$ & $N n$ & $n n$ & $N n$ & $n n$ \\
\hline & 14 & 198 & 0.59 & 0.32 & 0.68 & 0.00 & 0.86 \\
2 & 11 & 246 & 0.83 & 0.51 & 0.49 & 0.22 & 0.94 \\
3 & 10 & 176 & 0.88 & 0.00 & 1.00 & - & 0.88 \\
4 & 10 & 204 & 0.93 & 0.00 & 1.00 & - & 0.93 \\
5 & 9 & 151 & 0.92 & 0.00 & 1.00 & - & 0.91 \\
\hline
\end{tabular}

(1) Frequency of $n n$ in the SR line and $N N$ in the SS line was estimated to be 0.00 . Standard error of genotype frequency ranged from 0.10 to 0.12 in the SR line and 0.09 to 0.18 in the SS line, and standard error of penetrance ranged from 0.09 to 0.16 for $N n$ and 0.02 to 0.05 for $n n$.

(2) The partial dominance model fitted the data better than a recessive model at the $1 \%$ and $5 \%$ significance levels for generations 2 and 4 respectively.

\section{B. Inter-line crosses}

The overall proportion of halothane reactors observed in the $(\mathrm{SR} \times \mathrm{SS})$ and $(\mathrm{SS} \times \mathrm{SR}$ ) classes pooled over generations 3 to 5 was 0.20 (table 2) which is similar to the 0.22 estimated by CARDEN et al. (1983) for generation 1. As the gene was still segregating in the SR line at generation 5, data from the selection lines and inter-line crosses were pooled within generation, in order to provide a more sensitive test for 
heterozygous reactors. ML estimates of genoype frequency among parents of the SR line and penetrances were obtained and are shown in table 3 . These results did not differ significantly from the selection line results, except that the estimated proportion of heterozygous reactors was 0.03 in generation 3 . The majority of reactions in the inter-line classes could therefore be accounted for by the presence of $\mathrm{Nn}$ parents in the SR line.

TABLE 2

Number of animals and incidence of halothane reaction in the British Landrace inter-line crosses, pooled over generations 3,4 and 5

\begin{tabular}{l|c|c|c|c}
\hline \multicolumn{2}{c|}{ Selection line } & \multirow{2}{*}{$\begin{array}{c}\text { No. of } \\
\text { sires }\end{array}$} & $\begin{array}{c}\text { No } \\
\text { tested }\end{array}$ & $\begin{array}{c}\text { Offoportion } \\
\text { HP }\end{array}$ \\
\hline Sire & Dam & & 240 & 0.029 \\
SR & SR & 20 & 302 & 0.275 \\
SR & SS & 21 & 287 & 0.118 \\
SS & SR & 22 & 267 & 0.903 \\
SS & SS & 23 & & \\
\hline
\end{tabular}

TABIE 3

Estimates of genotype frequency in the SR line and penctrance estimates for pooled data from the British Landrace selection lines and inter-lines at generations 3, 4 and 5

\begin{tabular}{c|c|c|c|c|c|c|c}
\hline \hline \multirow{2}{*}{ Generation } & \multicolumn{3}{|c|}{ Genotype frequency (1) } & \multicolumn{4}{c}{ Penetrance } \\
\cline { 2 - 8 } & $N N$ & $N n$ & s.e. & $N n$ & s.e. & nn & s.e. \\
\hline \multirow{2}{*}{3} & 0.75 & 0.25 & 0.08 & $0.03(2)$ & 0.01 & 0.87 & 0.02 \\
4 & 0.64 & 0.36 & 0.08 & 0.00 & - & 0.93 & 0.02 \\
5 & 0.65 & 0.35 & 0.08 & 0.00 & - & 0.93 & 0.02 \\
\hline
\end{tabular}

(1) The SS line was assumed to be homozygous $(n n)$.

(2) The partial dominance model fitted the data better than the recessive model at the $1 \%$ significance level.

A reciprocal difference in incidence of reaction observed between the $(\mathrm{SS} \times \mathrm{SR})$ and $(\mathrm{SR} \times \mathrm{SS})$ classes was significant $(P<0.001)$ over all three generations (table 2$)$, with a higher proportion of reacting offspring coming from SS dams. This difference might be explained by a higher frequency of $N n$ sires than dams in the SR line. However, due to greater selection pressure on males its observed occurrence in each of the three generations was unlikely to be due to chance sampling alone $(P<0.01)$. An alternative hypothesis for the reciprocal difference is that a maternal influence on reaction, either genetic or environmental, gave rise to the higher incidence of reactors from SS dams. This effect was tested in the backcrosses. 


\section{Backcrosses}

A maternal effect can arise in either of two ways. Females from two lines may differ either in the cytoplasmic hereditary material transmitted to their offspring or in the maternal environment provided for their offspring. In each case, offspring would resemble their maternal line. Maternal determination of progeny phenotype from nutritional or behavioural differences would not be transmitted to the next generation, whereas cytoplasmic inheritance would persist undiminished through successive generations of females (Hutchison et al., 1974).

Results from the backcrosses $\mathrm{BC} 1, \mathrm{BC} 2$ and $\mathrm{BC} 3$ indicated little difference between reciprocal test matings in incidence, either within a backcross or over the pooled data (table 4). These data therefore provided no evidence to support a cytoplasmic form of inheritance of the halothane reaction. Also, the small proportion of reactions among offspring within the $\mathrm{SR} \times(\mathrm{SR} \times \mathrm{SS})$ and $\mathrm{SR} \times(\mathrm{SS} \times \mathrm{SR})$ classes may possibly be explained by the sires being $N n$.

\section{TABLE 1}

Proportion of halothane reaction (HP) in backcrosses 1,2 and 3

\begin{tabular}{|c|c|c|c|c|c|c|c|c|}
\hline \multirow{2}{*}{$\begin{array}{l}\text { Back- } \\
\text { cross }\end{array}$} & \multicolumn{2}{|c|}{ Selection line } & \multirow{2}{*}{$\begin{array}{l}\text { No. of } \\
\text { sires }\end{array}$} & \multirow{2}{*}{$\begin{array}{l}\text { No. of } \\
\text { litters }\end{array}$} & \multirow{2}{*}{$\begin{array}{l}\text { No. of } \\
\text { offspring }\end{array}$} & \multirow{2}{*}{$\begin{array}{c}\text { Proportion } \\
\text { HP }\end{array}$} & \multicolumn{2}{|c|}{ Significance ${ }^{(1)}$} \\
\hline & Sire & Dam & & & & & A & B \\
\hline \multirow[t]{4}{*}{$\mathrm{BCl}$} & SR & $\mathrm{SS} \times \mathrm{SR}$ & 7 & 15 & 92 & 0.02 & NS & NS \\
\hline & SR & $\mathrm{SR} \times \mathrm{SS}$ & 7 & 10 & 76 & 0.05 & $*$ & \\
\hline & SS & $\mathrm{SS} \times \mathrm{SR}$ & 7 & 10 & 58 & 0.38 & NS & NS \\
\hline & SS & $\mathrm{SR} \times \mathrm{SS}$ & 6 & 10 & 58 & 0.33 & $*$ & \\
\hline \multirow[t]{4}{*}{$\mathrm{BC} 2$} & SR & $\mathrm{SS} \times \mathrm{SR}$ & 5 & 11 & 88 & 0.08 & $* *$ & $* * *$ \\
\hline & SR & $\mathrm{SR} \times \mathrm{SS}$ & 5 & 9 & 75 & 0.00 & NS & \\
\hline & SS & $\mathrm{SS} \times \mathrm{SR}$ & 5 & 12 & 115 & 0.54 & NS & NS \\
\hline & SS & $\mathrm{SR} \times \mathrm{SS}$ & 4 & 7 & 63 & 0.43 & NS & \\
\hline \multirow[t]{2}{*}{$\mathrm{BC} 3$} & SS & $\mathrm{SS} \times \mathrm{SR}$ & 13 & 24 & 187 & 0.27 & $* * *$ & NS \\
\hline & SS & $\mathrm{SR} \times \mathrm{SS}$ & 12 & 19 & 122 & 0.27 & $* * *$ & \\
\hline \multirow[t]{4}{*}{ Total } & SR & $\mathrm{SS} \times \mathrm{SR}$ & 8 & 26 & 180 & 0.05 & $* *$ & NS \\
\hline & SR & $\mathrm{SR} \times \mathrm{SS}$ & 8 & 19 & 151 & 0.03 & $*$ & \\
\hline & SS & $\mathrm{SS} \times \mathrm{SR}$ & 23 & 46 & 360 & 0.37 & $* *$ & NS \\
\hline & SS & $\mathrm{SR} \times \mathrm{SS}$ & 24 & 36 & 243 & 0.33 & $* * *$ & \\
\hline
\end{tabular}

(1) Significance tests.

A : Comparison of observed and expected incidences where expected incidences are for a recessive gene with penetrance of $n n=0.90$, assuming homozygosity of the selection lines.

B : Comparison of reciprocal crosses within sire selection line.

Table 5 shows the incidence of reaction in each of the rour mating classes from BC4. The results are consistent with the hypothesis that all HP dams were $n n$ rather than the $N n$, as an average of 0.91 reactors were observed. For HP dams only, there was a significant difference $(P<0.05)$ in the proportion of reaction between progeny from $(S R \times S S)$ and $(S S \times S R)$ mothers. This may indicate that the maternal effect, if present, is only expressed in females of the HP phenotype. 
TABLE 5

Proportion of halothane reactors in backcross 4

\begin{tabular}{|c|c|c|c|c|c|c|c|c|}
\hline \multicolumn{2}{|c|}{ Selection line } & \multirow[b]{2}{*}{$\begin{array}{c}\text { Phenotype } \\
\text { of dam }\end{array}$} & \multirow{2}{*}{$\begin{array}{l}\text { No. of } \\
\text { sires }\end{array}$} & \multirow{2}{*}{$\begin{array}{l}\text { No. of } \\
\text { litters }\end{array}$} & \multirow[b]{2}{*}{$\begin{array}{l}\text { No. of } \\
\text { offspring }\end{array}$} & \multirow[b]{2}{*}{$\begin{array}{c}\text { Proportion } \\
\text { HP }\end{array}$} & \multicolumn{2}{|c|}{ Significance ${ }^{(1)}$} \\
\hline Sire & Dam & & & & & & A & B \\
\hline SS & $\mathrm{SS} \times \mathrm{SR}$ & HN & 5 & 6 & 36 & 0.50 & NS & NS \\
\hline SS & $\mathrm{SR} \times \mathrm{SS}$ & $\mathrm{HN}$ & 6 & 8 & 58 & 0.60 & & \\
\hline SS & $\mathrm{SS} \times \mathrm{SR}$ & HP & 3 & 3 & 23 & 0.83 & NS & $*$ \\
\hline SS & $\mathrm{SR} \times \mathrm{SS}$ & HP & 4 & 8 & 65 & 0.99 & & \\
\hline
\end{tabular}

(1) Significance tests.

A : Comparison of observed and expected incidences assuming sires all $n n$, HP dams $n n$ and HN dams $N n$ for a recessive gene with penetrance of $n n=0.90$.

B : Comparison of reciprocal crosses within phenotype of dam.

\section{Discussion}

Selection for a recessive character would be expected to result immediately in a line homozygous for the gene. Estimates of genotype frequency indicated that homozygosity was not achieved until the third generation in the SS line. This supported the partial dominance model in which heterozygous individuals could react. The partial dominance model gives a significantly better fit in only two cases out of ten, with estimates of 0.1 to 0.2 for the incidence of heterozygous reactors. However, these estimates did not differ significantly from zero.

This result differs from that of CARDEN et al. (1983) who reported that a model in which a proportion of heterozygotes react gave the better fit to data from generation 1 . It is possible that differences in the underlying assumptions gave rise to the different conclusions on the model of inheritance in the two studies. Both the SS and SR lines were analysed together in the CARDEN et al. (1983) analysis. It was assumed that parents of the first generation were a random and representative sample of the genotype frequencies within the founder herds, which is unlikely to have occurred. Misclassification of parental phenotypes would also lead to biases in genotype frequency estimates and subsequent estimation of penetrance. Later generations of the selection lines did not provide sufficient material to allow discrimination of genetic models, due to the presence of few segregating litters. Therefore, conclusions obtained from these analyses would need to be supported by similar observations from other studies.

Results from the inter-line crosses provided further evidence for the recessive model. Only in the generation 3 inter-line did a partial dominance model provide a better fit than the recessive, giving an estimate of 0.03 for the proportion of heterozygous individuals reacting. Southwood et al. (1988) and MERCER \& Southwood (1986) estimated that the proportion of heterozygotes reacting among British Landrace from 
test mating of commercial animals and within a British Landrace breeding herd was small (less than 0.02). Therefore, in this breed, there may be a slight departure from recessive inheritance, which may lead to the estimation of a small proportion of heterozygous reactors, depending on the origin of the data. The backcross BC4 could also be used to substantiate the recessive model. An average of 0.91 of offspring from HP dams reacted, which was to be expected if the dams were the genotype, $n n$.

The higher proportion of reactions in offspring which had a HP dam from the inter-lines suggested the presence of a maternal effect on halothane reaction. The genetic nature of this effect could not be confirmed from the backcrosses. However, the mechanism by which a maternal environmental effect could influence halothane reaction some weeks after weaning is at present unknown.

Selection against the halothane reaction by halothane testing can prove a rapid means of decreasing an initially high incidence of the reaction (MERCER \& SouTHwood, 1986). However, once the incidence is reduced to a low level, further elimination of the gene is slow and subject to chance sampling, as was seen in the SR line. Even with the probability of very few heterozygous reactors, the use of progeny testing to known halothane homozygotes would be an expensive option, both in number of offspring required and the resulting genetic lag. There is therefore a need for direct genotyping of animals. Linkage relationships with blood type genes (GAHNE \& JUNEJA, 1985) offer a method of increasing the rate to homozygosity, with the prospect of more accurate tests from DNA polymorphisms (Archibald, 1987) in the future.

These data suggest that the halothane reaction in British Landrace is inherited as partially dominant gene but with only a very small probability that a heterozygote may react, such as when the dam is also a reactor. Both this and the incomplete penetrance of the halothane homozygote affects the rate at which the gene can be eliminated, either by halotane testing of individuals, or by progeny testing. This underlines the need for a direct method for genotyping the heterozygote.

Received July 7, 1987.

Accepted October 23, 1987.

\section{Acknowledgements}

Thanks are expressed to the nine breeding companies who supplied animals for the foundation generation, and to the staff at Mountmarle and Skedsbush farms for collecting the halothane data.

\section{References}

ArChibald A.L., 1987. A molecular genetic approach to the porcine stress syndrome. In: Tarrant P.V., Eikelenboom G., Monin G. (ed.), In : Evaluation and control of meat quality in pigs, 343-357, Martinus Nijhoff, Dordrecht.

Cannings C., Thompson E.A., Skolnick M.H., 1978. Probability functions on complex pedigrees. Adv. App. Probab., 10, 26-81.

Carden A.E., Hill W.G., WebB A.J., 1983. The inheritance of halothane susceptibility in pigs. Génét. Sél. Evol., 15, 65-82. 
Eiffert L., Kallweit E., Glodek P., Smidt D., Groeneveld E., $1985 a$. Untersuchungen zum Halothantest in verschieden deutschen Schweinepopulationen. 1. Mitteilung : Ursachen von Fehleinstufungen beim Halothantest. Züchtungskunde, 57, 183-189.

Eiffert L., Kallweit E., Glodek P., Smidt D., Groeneveld E., 1985 b. Untersuchungen zum Halothantest in verschieden deutschen Schweinepopulation. 2. Mitteilung : Zur Vererbung der Halothanreaktion. Züchtungskunde, 57, 190-196.

Eikelendoom G., Minkema D., Van Eldik P., Sybesma W., 1978. Inheritance of the malignant hyperthermia syndrome in Dutch Landrace swine. In: Aldrete J.A., BritT B.A. (ed.), Second international symposium on malignant hyperthermia, 141-146, Grune and Stratton, New York.

Elston R.C., Stewart J., 1971. A general model for the genetic analysis of pedigree data. Hum. Hered, , 21; 523-542.

Gahne B., Juneja R.K., 1985. Prediction of the halothane (Hal) genotypes of pigs by deducing $\mathrm{Hal}$, Phi, $\mathrm{Po}$, $\mathrm{Pgd}$ haplotypes of parents and offspring : results from a large-scale practice in Swedish breeds. Anim. Blood Groups Biochem. Genet., 16, 265-283.

Hanset J.W., Leroy P., Michaux C., Kintaba K.N., 1983. The Hal locus in the Belgian Pietrain pig breed. Z. Tierz. Zücht. biol., 100, 123-133.

Hutchison C.A. III., Newbold J.E., PotTer S.S., Edgell M.H., 1974. Maternal inheritance of mammalian mitochondrial DNA. Nature, 251, 536-538.

LALouel J.M., 1979. GEMINI - A computer program for optimization of general non-linear functions. Technical report $n^{\circ} 14$, University of Utah.

Mabry J.W., Christian L.L., Kuhlers D.L., 1981. Inheritance of porcine stress syndrome. $J$. Hered., 72, 429-430.

Mercer J.T., Southwood O.I., 1986. Selection against halothane reaction in a commercial Landrace nucleus herd. In: Third world congress on genetics applied to livestock production, July 17-22, 1986, Lincoln, Nebraska, Vol. 10, 168-173, University of Nebraska, Lincoln.

Ollivier L., Sellier P., Monin G., 1978. Fréquence du syndrome d'hyperthermie maligne dans des populations porcines françaises; relation avec le développement musculaire. Ann. Génét. Sél. Anim., 10, 191-208.

Smith C., Bampton P.R., 1977. Inheritance of reaction to halothane anaesthesia in pigs. Genet. Res., Cambridge, 29, 287-292.

Southwood O.I., Simpson S.P., Curran M.K., WebB A.J., 1988. Estimated frequency of the halothane gene in British Landrace and Large White pigs. Anim. Prod., 46, 97-102.

Webr A.J., JoRdan C.H.C., 1978. Halothane sensitivity as a field test for stress susceptibility in the pig. Anim. Prod., 26, 157-168.

Webb A.J., Southwood O.I., Simpson S.P., Carden A.E., 1985. Genetics of porcine stress syndrome. In: Stress susceptibility and meat quality in pigs, EAAP Publication $n^{\circ} 33,9-30$. 